\title{
Desired Lifestyle of Older Adults with Dementia Living at Home from Their Perspective and That of Their Families with Support from Care Providers
}

\author{
Yumi Okinaka \\ Academic Field of Health Sciences, Okayama University, Okayama, Japan \\ Email: okky@okayama-u.ac.jp
}

How to cite this paper: Okinaka, Y. (2021) Desired Lifestyle of Older Adults with Dementia Living at Home from Their Perspective and That of Their Families with Support from Care Providers. Health, 13, 14601474.

https://doi.org/10.4236/health.2021.1312104

Received: November 12, 2021

Accepted: December 14, 2021

Published: December 17, 2021

Copyright $\odot 2021$ by author(s) and Scientific Research Publishing Inc. This work is licensed under the Creative Commons Attribution International License (CC BY 4.0).

http://creativecommons.org/licenses/by/4.0/

\begin{abstract}
Objective: This study aimed to determine the lifestyle of older adults with dementia living at home, how their families perceive them, and how care providers support their desired lifestyle. Methods: Semi-structured interviews were conducted with 12 pairs of older adults with dementia, their families, and care providers followed by a qualitative descriptive study. Results: Older adults with dementia described their lifestyle as follows: "I continue to take pride in the way I have lived so far," "I want to do what I can now even if I cannot do it well," "I live peacefully with my family," "I go out and interact with people," and "I live this time today with care." Families regarded the lifestyle of older adults with dementia as a desire "to continue living at home peacefully," "to live on their own," and that they "probably do not want anything." Care providers' support was based on "respect (for an older adult with dementia) as a person," "drawing out and making use of what they can do with their current abilities through providing care," "supporting families and confirming their sense of satisfaction with life," and "predicting the future course and supporting decision-making." Conclusions: To support the lifestyle of older adults with dementia, it is important to ensure that they continue to have dignity and are comfortable living with their families and in their communities without intimidation.
\end{abstract}

\section{Keywords}

Older Adults with Dementia, Life, Aging, Family, Home Care

\section{Introduction}

According to the World Health Organization (WHO), there are over 55 million 
people currently living with dementia worldwide and there are nearly 10 million new cases every year [1]. In Japan, it is estimated that one in five people will develop dementia in 2025, and it is expected to increase further in the future [2] [3]. Dementia is the first major cause of need for care in Japan, and there is a high need for care for older adults with dementia and their families living at home [4]. In previous surveys on the care for older adults with dementia, while the burden on care providers is occasionally explored, the main focus has been on support for the transition of older adults from facilities to their homes [5], visiting nurses' care practices for older adults with dementia [6], interventions for reducing the anxiety of care providers in the family [7], and review on care programs for local older adults with dementia in the community [8].

In the case of older adults with dementia, the discussion on the experiences associated with changes in symptoms and lifestyle has only just begun [9] [10] [11]. Older adults with dementia are said to be able to talk about their own past while being in a fluctuating time and space [12]. Despite dementia, they can live to an old age, which is a time to accept death and all of one's life (including the positive and negative parts), to live with interest in the next generation, and to integrate one's life [13]. Older adults with dementia have their own will, even if age-related changes and the dementia itself make it difficult to communicate accurately in words. Respect for will is imperative to ensure human dignity. When older adults with dementia find it difficult to live alone without the support of others, the care provider determines how they shall live, which is dependent on how the support from the immediate family. However, understanding how older adults with dementia want to live is critical to having families and care providers respect them as people, respect their will, and support the integration in their life.

However, no studies have focused on how older adults with dementia who live at home want to live, and how families who care for them on a daily basis understand their thoughts and support them. This is critical in helping older adults with dementia live out their old age independently, even if the dementia makes it difficult for them to organize and manage their own lives.

Therefore, this study aims to clarify what kind of life older adults with dementia living at home desire, how families perceive this, and how care providers can support their desired lifestyles.

\section{Method}

\subsection{Participants}

The participants in this study of 12 pairs of older adults with dementia using in-home, long-term support or home-visit nursing care offices through the longterm care insurance system, their families, and their care providers (Table 1).

\subsection{Procedures}

The purpose of the study was explained to the managers of in-home, long-term 
Table 1. Overview of the participants.

\begin{tabular}{|c|c|c|c|c|c|c|c|c|c|c|c|c|}
\hline \multirow[b]{2}{*}{ Participant } & \multicolumn{6}{|c|}{ Older adults with dementia } & \multicolumn{3}{|c|}{ Family } & \multicolumn{3}{|c|}{ Care provider } \\
\hline & Gender & Age & $\begin{array}{l}\text { Dementia } \\
\text { diagnosis }\end{array}$ & $\begin{array}{l}\text { Everyday life } \\
\text { independence } \\
\text { 1) }\end{array}$ & $\begin{array}{l}\text { Main } \\
\text { service }\end{array}$ & $\begin{array}{l}\text { Family } \\
\text { structure } \\
\text { and } \\
\text { members }\end{array}$ & Relationship & Age & $\begin{array}{c}\text { Cohabitation } \\
\text { and } \\
\text { separation }\end{array}$ & Job type & Age & $\begin{array}{c}\text { Years of } \\
\text { experience }\end{array}$ \\
\hline A & Female & $\begin{array}{l}\text { Early } \\
90 \mathrm{~s}\end{array}$ & $\begin{array}{l}\text { Alzheimer's } \\
\text { dementia }\end{array}$ & IIb & $\begin{array}{c}\text { Outpatient } \\
\text { rehabilitation }\end{array}$ & $\begin{array}{l}\text { Son, } \\
\text { Son's } \\
\text { wife }\end{array}$ & Son & $\begin{array}{l}\text { Late } \\
60 \mathrm{~s}\end{array}$ & $\begin{array}{l}\text { Living } \\
\text { together }\end{array}$ & $\begin{array}{l}\text { Long-Term } \\
\text { Care } \\
\text { Support } \\
\text { Specialists }\end{array}$ & $\begin{array}{l}\text { Late } \\
30 \mathrm{~s}\end{array}$ & 6 years \\
\hline B & Female & $\begin{array}{c}\text { Early } \\
80 \mathrm{~s}\end{array}$ & $\begin{array}{l}\text { Argyrophilic } \\
\text { grain } \\
\text { dementia }\end{array}$ & IIb & Day care & $\begin{array}{c}\text { Son, } \\
\text { Son's wife, } \\
\text { Grandchild }\end{array}$ & Son's wife & $\begin{array}{l}\text { Early } \\
50 \mathrm{~s}\end{array}$ & $\begin{array}{l}\text { Living } \\
\text { together }\end{array}$ & $\begin{array}{l}\text { Long-Term } \\
\text { Care } \\
\text { Support } \\
\text { Specialists }\end{array}$ & $\begin{array}{l}\text { Early } \\
60 \mathrm{~s}\end{array}$ & 9 years \\
\hline $\mathrm{C}$ & Female & $\begin{array}{l}\text { Early } \\
100 \mathrm{~s}\end{array}$ & $\begin{array}{l}\text { Alzheimer's } \\
\text { dementia }\end{array}$ & IIb & $\begin{array}{l}\text { Home nursing } \\
\text { Outpatient } \\
\text { rehabilitation } \\
\text { Visiting } \\
\text { medical care }\end{array}$ & $\begin{array}{l}\text { Daughter, } \\
\text { Daughter's } \\
\text { husband }\end{array}$ & Daughter & $\begin{array}{l}\text { Late } \\
70 \mathrm{~s}\end{array}$ & $\begin{array}{l}\text { Living } \\
\text { together }\end{array}$ & $\begin{array}{l}\text { Long-Term } \\
\text { Care } \\
\text { Support } \\
\text { Specialists }\end{array}$ & $\begin{array}{l}\text { Late } \\
50 \mathrm{~s}\end{array}$ & 7 years \\
\hline $\mathrm{D}$ & Male & $\begin{array}{l}\text { Early } \\
80 \text { s }\end{array}$ & $\begin{array}{c}\text { Alzheimer's } \\
\text { dementia }\end{array}$ & IIIb & $\begin{array}{l}\text { Outpatient } \\
\text { rehabilitation }\end{array}$ & Wife & Wife & $\begin{array}{l}\text { Late } \\
70 \mathrm{~s}\end{array}$ & $\begin{array}{l}\text { Living } \\
\text { together }\end{array}$ & $\begin{array}{l}\text { Long-Term } \\
\text { Care } \\
\text { Support } \\
\text { Specialists }\end{array}$ & $\begin{array}{l}\text { Late } \\
50 \mathrm{~s}\end{array}$ & 7 years \\
\hline $\mathrm{E}$ & Female & $\begin{array}{l}\text { Late } \\
80 \text { s }\end{array}$ & $\begin{array}{l}\text { Alzheimer's } \\
\text { dementia }\end{array}$ & IIIb & $\begin{array}{l}\text { Day care } \\
\text { Short-term } \\
\text { admission }\end{array}$ & $\begin{array}{l}\text { Son, Son's } \\
\text { wife }\end{array}$ & Son's wife & $\begin{array}{l}\text { Late } \\
50 \mathrm{~s}\end{array}$ & $\begin{array}{l}\text { Living } \\
\text { together }\end{array}$ & $\begin{array}{l}\text { Long-Term } \\
\text { Care } \\
\text { Support } \\
\text { Specialists }\end{array}$ & $\begin{array}{l}\text { Late } \\
50 \mathrm{~s}\end{array}$ & 6 years \\
\hline $\mathrm{F}$ & Male & $\begin{array}{c}\text { Early } \\
80 \text { s }\end{array}$ & $\begin{array}{l}\text { Alzheimer's } \\
\text { dementia }\end{array}$ & $\mathrm{IIb}$ & $\begin{array}{l}\text { Home nursing } \\
\text { Outpatient } \\
\text { rehabilitation } \\
\text { Short-term } \\
\text { admission }\end{array}$ & $\begin{array}{l}\text { Wife, } \\
\text { Daughter, } \\
\text { Grandchild }\end{array}$ & Wife & $\begin{array}{l}\text { Early } \\
80 \mathrm{~s}\end{array}$ & $\begin{array}{l}\text { Living } \\
\text { together }\end{array}$ & $\begin{array}{l}\text { Visiting } \\
\text { nurse }\end{array}$ & $\begin{array}{l}\text { Early } \\
50 \mathrm{~s}\end{array}$ & 8 years \\
\hline G & Female & $\begin{array}{l}\text { Late } \\
80 \mathrm{~s}\end{array}$ & $\begin{array}{l}\text { Alzheimer's } \\
\text { dementia } \\
\text { Vascular } \\
\text { dementia }\end{array}$ & IV & $\begin{array}{l}\text { Day care } \\
\text { Long-term } \\
\text { stay }\end{array}$ & $\begin{array}{l}\text { Husband, } \\
\text { Daughter, } \\
\text { Daughter's } \\
\text { husband }\end{array}$ & Daughter & $\begin{array}{l}\text { Late } \\
50 \mathrm{~s}\end{array}$ & $\begin{array}{l}\text { Living } \\
\text { together }\end{array}$ & $\begin{array}{l}\text { Long-Term } \\
\text { Care } \\
\text { Support } \\
\text { Specialists }\end{array}$ & $\begin{array}{l}\text { Late } \\
50 \mathrm{~s}\end{array}$ & 6 years \\
\hline $\mathrm{H}$ & Female & $\begin{array}{l}\text { Early } \\
80 \text { s }\end{array}$ & $\begin{array}{l}\text { Alzheimer's } \\
\text { dementia } \\
\text { Lewy body } \\
\text { dementia }\end{array}$ & $\mathrm{IIb}$ & $\begin{array}{c}\text { Outpatient } \\
\text { rehabilitation }\end{array}$ & $\begin{array}{l}\text { Living } \\
\text { alone } \\
\text { Daughter } \\
\text { living } \\
\text { nearby }\end{array}$ & Daughter & $\begin{array}{l}\text { Early } \\
60 \mathrm{~s}\end{array}$ & Separation & $\begin{array}{l}\text { Long-Term } \\
\text { Care } \\
\text { Support } \\
\text { Specialists }\end{array}$ & $\begin{array}{l}\text { Late } \\
50 \mathrm{~s}\end{array}$ & 14 years \\
\hline I & Male & $\begin{array}{l}\text { Early } \\
90 \mathrm{~s}\end{array}$ & $\begin{array}{l}\text { Alzheimer's } \\
\text { dementia }\end{array}$ & IIb & Day care & Wife & Wife & $\begin{array}{l}\text { Late } \\
80 \mathrm{~s}\end{array}$ & $\begin{array}{l}\text { Living } \\
\text { together }\end{array}$ & $\begin{array}{l}\text { Long-Term } \\
\text { Care } \\
\text { Support } \\
\text { Specialists }\end{array}$ & $\begin{array}{l}\text { Late } \\
40 \mathrm{~s}\end{array}$ & 18 years \\
\hline $\mathrm{J}$ & Female & $\begin{array}{l}\text { Late } \\
80 \text { s }\end{array}$ & $\begin{array}{c}\text { Alzheimer's } \\
\text { dementia }\end{array}$ & IV & $\begin{array}{c}\text { Home } \\
\text { nursing } \\
\text { Day care }\end{array}$ & Husband & Husband & $\begin{array}{l}\text { Late } \\
80 \mathrm{~s}\end{array}$ & $\begin{array}{l}\text { Living } \\
\text { together }\end{array}$ & $\begin{array}{l}\text { Physical } \\
\text { therapist }\end{array}$ & $\begin{array}{l}\text { Early } \\
40 \mathrm{~s}\end{array}$ & 19 years \\
\hline K & Female & $\begin{array}{l}\text { Late } \\
70 \mathrm{~s}\end{array}$ & $\begin{array}{l}\text { Alzheimer's } \\
\text { dementia }\end{array}$ & IIIb & $\begin{array}{c}\text { Home } \\
\text { nursing } \\
\text { Home-Visit } \\
\text { Rehabilitation }\end{array}$ & $\begin{array}{l}\text { Husband, } \\
\text { Son }\end{array}$ & Husband & $\begin{array}{l}\text { Late } \\
70 \mathrm{~s}\end{array}$ & $\begin{array}{l}\text { Living } \\
\text { together }\end{array}$ & $\begin{array}{l}\text { Long-Term } \\
\text { Care } \\
\text { Support } \\
\text { Specialists }\end{array}$ & $\begin{array}{l}\text { Early } \\
60 \mathrm{~s}\end{array}$ & 19 years \\
\hline
\end{tabular}




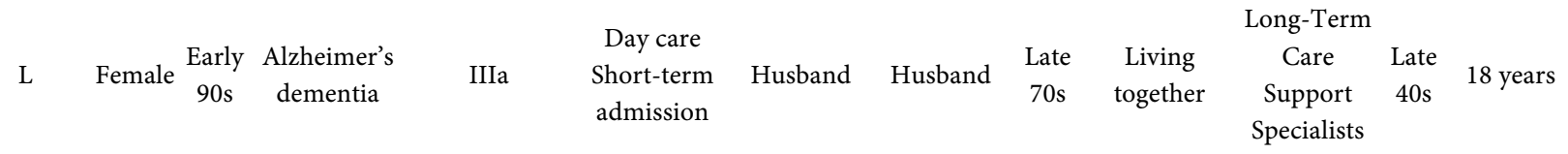

Note 1) The degree of independence in daily life of older adults with dementia ranges from Rank I (almost independent) to Rank IV (always requiring care). II and III are classified as a and b, respectively.

care support (Office 1) and home-visit nursing care (Office 2) locations in the Chugoku and Shikoku regions of Japan, and informed consent was obtained for their cooperation in the study. The researchers then contacted the older adults with dementia, their families, and their care providers, and asked for their cooperation directly.

Ethical considerations included verbal explanations to the participants, their families, and care providers about the purpose of the study and the protection of personal information, freedom to decline, disclosure of results and adherence to anonymity, protection of privacy, and no disadvantages to current use services and work evaluations in the absence of cooperation. Interviews were tailored to the circumstances of the individual, family, and care provider. In addition, during the interview, the physically altered conditions of the participants were taken into consideration. This study was conducted with the approval of the Research Ethics Review Board (T17-08) of the affiliated universities.

\subsection{Data Collection and Analysis}

The study adopted a qualitative descriptive study design. Individual interviews were conducted using a semi-structured method based on an interview guide. Participants were asked how they would like to live based on their past life experiences; families were asked what kind of life they thought the participants desired; and care providers were asked how the participants would like to live and what kind of care they received. Each interview was conducted for approximately 60 minutes. The participants and their families were interviewed at home, and care providers were interviewed at the office where they worked. The interviews were recorded on an IC recorder, and verbatim data was used for analysis. The data collection period was from April 2018 to December 2018.

Initially, I repeatedly read the verbatim interview content to gain a deeper understanding of their narratives. Next, the following questions were asked to each set of respondents: "What is the desired life of older adults with dementia?" "How do family members and care providers perceive the desired life of older adults with dementia?" and "What kind of support are care providers providing?" The responses were then extracted and coded. In addition, the commonality and divergence of the codes extracted from the 12 pairs were considered and categorized.

To ensure rigor in the qualitative research, the content of the interviews was checked with the participants and the results of the analysis were communicated to the care providers to ensure the credibility of the content and the analysis. 


\section{Results}

There were five kinds of lifestyles desired by participants, three lifestyles desired by the families, and four categories of support by care providers which support the lifestyles desired by the older adults with dementia.

\subsection{Lifestyles Desired by Older Adults with Dementia (Table 2)}

Participants living at home had a sense of accomplishment and fulfillment that they had done their best in their life experiences, both inside and outside their homes. They talked about the life events they had worked so hard to achieve in their lives, and how they felt they were still the same self they were then, and that they continued to have pride. Despite their old age, they continue to live with pride and have strong beliefs and personalities. Although they were aware that the symptoms of dementia would lead to a decrease in their ability to function as usual, the participants wanted to continue doing what they could to live a life of pleasure every day.

In addition, participants wanted to be supported by their children and grandchildren, and elderly couples wanted to help each other while living peacefully with their families. Their responses included the following: "In my daily life, I am aware that the symptoms of dementia make it difficult to establish relationships with others or to go out, but I wanted to go out and live and interact with people" and "Looking back on my life so far and imagining the future, I hope that my casual present daily life would continue, and that I have lived cherishing this time today."

\subsection{Family-Captured Lifestyles of Older Adults with Dementia (Table 3)}

Participants' family members believed that they would continue their own lifestyle (e.g., housework or other habits which they had been doing since their youth), interact with local people, and continue to live in their homes in the future. Families that had been living together before the dementia set in understood the distress of the participants due to the fact that they were not be able to live as they desired because of their symptoms. They believed that as the symptoms progressed, the anguish would pass and the participants would no longer be under distress.

\subsection{Support by the Care Providers of Older Adults with Dementia (Table 4)}

The participants' care providers revealed that the participants frequently talked about and took pride in their work and educational background. The care providers conveyed to the participants that they were indeed necessary and respected as people, taking care not to deny their words or behaviors. In addition, the care providers encouraged the older adults under their care to make use of the work and hobbies which they had always done in their lives, ascertained 
Table 2. Desired lifestyle of older adults with dementia living at home.

\begin{tabular}{|c|c|c|}
\hline Category & Code & Main narratives \\
\hline \multirow{5}{*}{$\begin{array}{l}\text { I continue to } \\
\text { be proud of my } \\
\text { way of life to date. }\end{array}$} & I live with pride. & $\begin{array}{l}\text { She repeatedly talked about her unforgettable time as a student } \\
\text { and the work she worked so hard on. "I still think my pride is } \\
\text { strong. But it doesn't go through to others. I'll forget it," } \\
\text { she said. "In fact, I forget. I do not remember." (A) }\end{array}$ \\
\hline & $\begin{array}{l}\text { I maintain my beliefs } \\
\text { in order to survive. }\end{array}$ & $\begin{array}{l}\text { I had a hard time as a peasant's wife, but I managed to live. } \\
\text { I think, "there is nothing that other people do that I can't do." (C) }\end{array}$ \\
\hline & I keep my age very self-evident. & I feel so young that I don't look like I am 80 years old. (D) \\
\hline & \multirow{2}{*}{$\begin{array}{l}\text { I still have a sense of } \\
\text { accomplishment and } \\
\text { fulfillment in my work. }\end{array}$} & $\begin{array}{l}\text { I was happy when I could have my own factory at work. } \\
\text { I still feel like I'm getting a job and doing it myself. (F) }\end{array}$ \\
\hline & & $\begin{array}{l}\text { It was rewarding that I was able to do work I considered difficult. } \\
\text { I have been working for my family. I think it will help children } \\
\text { to live long now. (I) }\end{array}$ \\
\hline
\end{tabular}

It's fun to be able to go to work (day care). I am happy that the care staff tells me what I can do (G).

My husband does the shopping, and I do the cooking andcleaning. It was difficult at first. (K)

There's something I can do now, even if I'm going to forget more.
I want to do what I can now, even if I can't do it well.
I always enjoy myself through the hobbies I can do now.
I used to do tea and flower arrangements when I was young, but I forgot them all. I'm doing things to the extent that I can, such as drying the laundry, bringing it in, ironing it, and doing things in the house. (B)

Even now, I have confidence in shogi. When you get older, it is positive. "Let's play shogi," he said, because he came up. (D)

I want to work more, even if I I want to do more work in my 50s and 60s, even if I can't do it as didn't like it when I was young. $\quad$ well as I could when I was young $(F)$.

I liked to arrange flowers. The bride would take me to the bridal exhibition. When you think about how to arrange flowers, it's fun and rewarding. (B)

I have a friend who can play shogi, and I'm happy to be able to do whatever I like (D).

I have nothing to look forward to, but I'm making bead necklaces (L).

My wife is kind and my grandson is with me. My family is good. I have nothing more to say. It's fine as it is now.

I am the happiest now. (B)

I feel happiest now, when

I live peacefully with family. I live peacefully with my family.

There is nothing to worry about because the children, wife, and the family are all well (G).

My wife who takes care of me doesn't get angry, and I'm thankful that she does everything. There's nothing to hide. (E)

Dad (said about her husband), live a long life. I want you to be by my side because I'm in trouble. (K)

Being an elderly couple, we live together by supporting each other.
In old age, neither your thoughts nor your body are free. I wish I could be firm. There are only 2 of us, me and my husband, so neither one of us can fall down. (J) 


\section{Continued}

\begin{tabular}{|c|c|c|}
\hline \multirow{4}{*}{$\begin{array}{l}\text { I want to go out } \\
\text { and interact } \\
\text { with people. }\end{array}$} & & $\begin{array}{l}\text { I'm glad to talk to you today. Where I was born and raised, } \\
\text { people gathered and talked well. Now I can't understand my mind. } \\
\text { I don't talk to neighbors. (A) }\end{array}$ \\
\hline & $\begin{array}{l}\text { I want to get in contact } \\
\text { with people and talk. }\end{array}$ & $\begin{array}{l}\text { When you are } 100 \text { years old, you are no longer in touch with } \\
\text { others and you can't be happy living. (C) }\end{array}$ \\
\hline & & $\begin{array}{l}\text { I got angry, got into trouble with my neighbors, and I couldn't } \\
\text { go out }(\mathrm{K}) \text {. }\end{array}$ \\
\hline & I want to go out of the house. & $\begin{array}{l}\text { I would be happy if I could take a walk with my husband or take } \\
\text { it with you. But if you ask a man to walk hand-in-hand, everyone } \\
\text { will see it. I'm fine, but I think my husband will not like it. (J) }\end{array}$ \\
\hline \multirow{3}{*}{$\begin{array}{l}\text { I care about } \\
\text { living in } \\
\text { the present. }\end{array}$} & $\begin{array}{l}\text { I want a continuation of } \\
\text { a carefree daily life. }\end{array}$ & $\begin{array}{l}\text { I wish I could eat breakfast, lunch, and dinner at home and have } \\
\text { delicious side dishes. Anyway, I want to stay well while I'm alive, } \\
\text { so as to be able to move without illness. (I) }\end{array}$ \\
\hline & I want to continue to live in peace. & $\begin{array}{l}\text { I want to live in peace. I hope my current life continues. } \\
\text { I want to age as much as possible. I don't want to go into the } \\
\text { grave yet. }(\mathrm{K})\end{array}$ \\
\hline & It was a good life. & $\begin{array}{l}\text { It was a good life. I was happy. The future may come, } \\
\text { but I will do my best. (G) }\end{array}$ \\
\hline
\end{tabular}

Note. The alphabet indicates older adults with dementia.

Table 3. Lifestyle desired by older adults with dementia as perceived by family members.

\begin{tabular}{|c|c|c|}
\hline Category & Code & Main narratives \\
\hline \multirow{6}{*}{$\begin{array}{l}\text { I want to continue } \\
\text { living at home } \\
\text { peacefully as it is. }\end{array}$} & $\begin{array}{l}\text { I would like to continuing } \\
\text { the lifestyle habits of the past. }\end{array}$ & $\begin{array}{l}\text { My mother-in-law believes that housework is her own role, } \\
\text { and it is becoming a lifestyle habit. (B) }\end{array}$ \\
\hline & $\begin{array}{l}\text { I would like to talk because I have } \\
\text { less interaction with acquaintances } \\
\text { and neighbors and I feel lonely. }\end{array}$ & $\begin{array}{l}\text { All of the people of my mother's age have passed away and I feel } \\
\text { that my mother's surroundings have become quiet. There is a } \\
\text { reality that even if you want to talk, as you used to, you can't. (A) }\end{array}$ \\
\hline & $\begin{array}{l}\text { I'm still happy that } \\
\text { I'm living like myself. }\end{array}$ & $\begin{array}{l}\text { My husband was very careful when he was working for the } \\
\text { company. Because of this, I am still well prepared (D). }\end{array}$ \\
\hline & \multirow{3}{*}{$\begin{array}{l}\text { I would like to continue } \\
\text { living at home as it is now. }\end{array}$} & $\begin{array}{l}\text { My mother-in-law has lived here since I got married, so she'll } \\
\text { want to stay home for a long time. When daughters or } \\
\text { grandchildren come, they go out together. You'll want to live } \\
\text { as you are. (E) }\end{array}$ \\
\hline & & $\begin{array}{l}\text { He would like to live at home as much as possible. However, } \\
\text { as his function declines, as a daughter, I would like him to } \\
\text { enter a facility. }(\mathrm{H})\end{array}$ \\
\hline & & $\begin{array}{l}\text { My husband is worried about how much he can live on his } \\
\text { pension. He was relieved to hear me say that there was no } \\
\text { inconvenience. I think he would like to continue living as } \\
\text { it is now. (I) }\end{array}$ \\
\hline $\begin{array}{l}\text { I want to live } \\
\text { my own life. }\end{array}$ & I want to work and move. & $\begin{array}{l}\text { My mother has been tailoring kimonos while being a farmer. } \\
\text { She wouldn't want to do anything now. Everyday, you're saying } \\
\text { "What shall I do?" so you want to work. (C) }\end{array}$ \\
\hline
\end{tabular}


My mother will find it painful if there is something she can't do. There are instances when she keeps her face down without talking. (G)

Is it because she is spoiled that she does not move? I think I may be angry and grit my teeth (J).

My mother had a very hard life. I think she feels at ease now.

I will be giving up on my current life. I'm giving up on that and I have no choice but to be satisfied with my current life. $(\mathrm{H})$

I don't think my wife thinks much of anything anymore.

She probably never thought of being in such a state.

I wouldn't think of anything.

but she doesn't know anymore. $(\mathrm{K})$

What about the life my wife wants? I don't say anything in particular, I just sleep now. (L)

Note. The alphabet refers to older adults with dementia and their families.

Table 4. Supporting care providers to assure the desired lifestyle of older adults with dementia.

\begin{tabular}{|c|c|c|}
\hline Category & Code & Main narratives \\
\hline \multirow{3}{*}{ Respect as individuals } & $\begin{array}{c}\text { Celebrate proud feelings } \\
\text { of work, academic background, etc. }\end{array}$ & $\begin{array}{l}\text { She repeatedly talks about girls' schools and work. I told } \\
\text { her that I want to talk, so I listened while praising. (A) } \\
\text { Tell my daughter, "You're a smart, wonderful mother } \\
\text { in the truest sense." (C) }\end{array}$ \\
\hline & Do not deny words and actions & $\begin{array}{l}\text { I do recreational activities that I am good at, } \\
\text { not too easy to make a fool of myself. (F) } \\
\text { Some people are not aware of dementia. } \\
\text { It is a sensitive area so be delicate and not irritating. (H) } \\
\text { Tell the person in question who does not try to move } \\
\text { on his or her own and their spouse that they are } \\
\text { "doing their best". (J) }\end{array}$ \\
\hline & Be recognized as a necessary entity & $\begin{array}{l}\text { Tell the person that they are useful to the family by their } \\
\text { doing the housework. (B) } \\
\text { Hold games on day service and give a certificate of award. } \\
\text { When he is called a shogi teacher, he is very happy. } \\
\text { I think I'm needed so much. (D) }\end{array}$ \\
\hline $\begin{array}{l}\text { Bringing out and } \\
\text { leveraging what you } \\
\text { can do with } \\
\text { your current capabilities } \\
\text { and linking care }\end{array}$ & $\begin{array}{l}\text { Determine what you can do by } \\
\text { taking advantage of the work and } \\
\text { hobbies you have done over the years. }\end{array}$ & $\begin{array}{l}\text { I heard from my family that I couldn't walk by myself, but } \\
\text { I pushed the wheelchair and moved about the room (C). } \\
\text { Look at what you can do, what you are good at, and } \\
\text { how much you can make use of your abilities. } \\
\text { Consider whether you can live at home for as long as } \\
\text { possible, so as not to undermine your current life. (H) } \\
\text { Try to do what you liked before. Even if you don't } \\
\text { remember it in your mind, your hands still remember it. } \\
\text { Pull it out. (F) }\end{array}$ \\
\hline
\end{tabular}




\section{Continued}

I make one attempt at what I was good at and make them think I was able to do it. (F)

Tell the day service that you have been able to do home-visit nursing and will continue to do so. (F)

Sharing information with multiple organizations and occupations and linking care involvement and hard work

Assess the burden of long-term care and provide guidance on long-term care skills

See if older adults with dementia and their families live peacefully.
I have heard that they are good at knitting, dressmaking, and Japanese dressmaking, so I have shared information with the staff so that they can do something with the day service $(\mathrm{H})$.

She told her husband, "You can't move because you have dementia, but you can't do it." He said,

"You can't help because you're ill," and she said,

"You've worked hard" (L).

Say to a wife who is worried about her husband's memory impairment, "Maybe it's something you want to forget”. (I)

When I first heard my mother-in-law say "I think of my daughter-in-law as my own daughter", I was so happy and I want to take more care of her. (B)

I tell my husband that "I am a person who does not change with age” (L).

In visiting rehabilitation, we focus on how much the person is moving, what kind of care the family is providing, and how much they are burdened. (J)

Tell your husband that speaking and laughing during meals are important things that your family can give you. (L)

No matter how many times she hears the same thing, each time she answers, laughing, rather than being gentle or angry. So, those two feel good, and I think they'll continue to the end. (C)

The chair in the living room is in his position, and he is always with the dog in the sun. (E)

I think I'm happy now because of my facial expression and conversation with my husband (L).

I love to interact with people, so I would like to live with friends and everybody in the community as I am connected with them. I also see a couple walking hand-in-hand in the park. (D)

Home-visit nurses must be familiar not only with illness but also with life. Otherwise it is unacceptable to the individual or family. (F)

I wonder where it is comfortable for the person per se. Coordinate use of services in areas where the individual can enjoy living. (G) 
I can understand how he wants to continue his current life for as long as possible. I think there is a conflict in accepting a new environment. In the midst of a variety of services, gradually proceed through the stages. $(\mathrm{H})$

The person believes that the day service he uses is going to work and says he is satisfied. I am talking with my eldest daughter $(\mathrm{G})$ that, in view of the progression

Confirm with family members where and how the older adult would meet the end of their life. of dementia, admission to an institution is unavoidable because of the burden on my older adult husband's body. (G)

Think about how you want to end your service as you coordinate it. I hope my family will be satisfied with nursing care at the final stage. (I)

Note. The alphabet indicates a caregiver for the older adult with dementia.

what was possible for them to do based on their present abilities, and asked them to actively pursue these activities. These care providers also guided others who care for older adults with dementia on what was done and what could be done, and coordinated care activities to ensure their uninterrupted longevity.

The care providers also believed that it was better for older adults with dementia to live with their families, and that familial support is important for the lifestyle desired by older adults to be realized. Care providers were comfortable discussing the families' feelings, praised their daily care practices, assessed the burden of care, and provided additional care skills. They also checked whether the participants and their families lived peacefully and were satisfied. In addition, the participants anticipated the future course of the care they needed in consideration of the environment in which they could live comfortably with their families and communities. They also communicated and confirmed with their families where and how they would like to be at the end of their lives and were supported in their decisions.

\section{Discussion}

The participants wanted to continue taking pride their own way of life, live peacefully with their families, and interact with others, while valuing the time they had at present. The participants' families who had lived with them understood their lifestyles, and their care providers supported these lifestyles. Based on the results of these analyses, we discussed the continued dignity of older adults with dementia and the place where they can be most comfortable without their egos being threatened.

\subsection{Continuing Dignity of Older Adults with Dementia}

Older adults with dementia wanted to remain proud of their way of life. They used to work for their families, and this work was a part of the brilliant life expe- 
rience of confronting difficulties, overcoming them, and gaining a sense of accomplishment. They also supported their families through housework. The participants live with the desire to do what they can now, in their unexpected confusion. Family members are familiar with the work and hobbies that these participants have conducted for the family and for self-realization, the beliefs and values they have cherished, and the history of their hardships and pleasures. It has been reported that older adults with dementia deepen their self-affirmation and maintain a rich life with pleasure and a lifelong role in their families [10]. Even if older adults with dementia find it difficult to speak on their own, their families understand their sense of pride. To recognize their pride is to dignify them as a person. Care providers therefore need to listen to the life experiences of older adults with dementia and understand their values and beliefs from them directly and from their families who are familiar with them. Even though older adults with dementia may be incapable of regular movement or may have become increasingly forgetful, they are still able to recognize that they are needed and useful to others through activities that they perceive as something that they can do for their families.

In contrast, older adults with dementia may also give up without trying because they have had experiences of not being able to accomplish tasks or have had negative feelings at the time they wanted to do something. Studies show that exhibiting caring, considering, friendly, and helpful attitudes towards an older adult with dementia shows respect for that person [14]. Care providers should not only focus on what older adults with dementia cannot do, but should draw out their abilities and encourage them to think it possible, based on their past life experiences. In addition, it is important for older adults with dementia to work not only with words but also with the body. By verbalizing and acknowledging what older adults with dementia can do, and by accumulating experiences that make them feel "I can do it," their self-efficacy will increase. The sense of accomplishment regarding what they have achieved and recognizing that their experience seems to be helpful to others can help them feel worthy and lead to enjoyment in their daily lives. It is also important to share information and connect experiences of achievement and joy among the care services they utilize.

\subsection{Comfortable Place for Older Adults with Dementia without Threatening Their Egos}

Older adults with dementia want to live peacefully with their families, go out and interact with people, and cherish the time they have together. They feel easily unstable regarding their ego because they recognize time, places, and people differently from the real world due to memory loss and disorientation. In addition, older adults with dementia are said to want to live peacefully in a safe environment with a social support network of people close to them who can be trusted, such as family members and care providers [10]. If an older adult with dementia feels that a particular place is safe, they will not be threatened and will be able to spend life peacefully. 
Older adults with dementia have physical locations where they live, psychological locations where they feel they can live, and social locations formed through relationships and roles with others [15]. Participants of this study maintained good relationships with their families and communities, such as couples, parents and children, and neighbors who had lived together for a long period of time. Even though older adults with dementia lose their sense of time, place, and people, there is certainly a human and spatial location where they can feel comfortable without being threatened by anything, which is manifested as living with family with whom they maintain a good relationship. If one can feel at home within their family, they would be able to spend their time peacefully. To facilitate this, it is necessary to support the families who live with them. In Japan, since married couples account for the largest number of households with persons aged 65 or older, the family caregiver is often the elderly spouse. Elderly spouses tend to have a greater burden of nursing care on them [16]. However, if support can be provided to meet the needs of the family care providers, the sense of nursing burden can be reduced [17]. Therefore, to ensure a comfortable place for older adults with dementia, it is important to coordinate care services in order to work out the care that families provide on a daily and yearly basis to provide guidance on individual nursing care skills, provide repeated consultations, and support decision-making while anticipating future progress.

Contrarily, people with dementia are connected to society while controlling themselves based on values and beliefs that they want to be themselves until the end of their lives [18]. They feel lonely due to the reduced opportunities to interact with others owing to the bereavement of neighbors and friends of the same generation as well as the loss of sense of time and place associated with dementia. Cognitive function and living environment are closely related to social participation [19]. People with dementia have been reported to experience a narrowing of living space with progression of symptoms [20]. However, in areas where older adults with dementia have become accustomed to living, there are places where people can interact with nature and participate in society. Therefore, linking older adults with their families and to people in the community may guarantee a comfortable place for them. Furthermore, the involvement of volunteers is expected to have a positive impact on their health [21]. It is important to provide opportunities for older adults with dementia to participate in society together with their families and to help them feel that they are living in close contact with the community.

\subsection{Recommendations for Care That Supports the Desired Lifestyles of Older Adults with Dementia}

In order to support older adults with dementia, it is important to listen to their past life experiences, recognize their sense of pride, make them feel fulfilled and happy in their living situations by helping them utilize their remaining functions, and share information with other organizations and across various occupations to form connected care practices. In addition, it is important to confirm 
whether older adults with dementia have places where they can feel comfortable without their egos being threatened, and to support them through social participation together with their families so that they can remain connected to the community.

\section{Limitations}

The results of this study were based on the analysis of discussions with older adults with dementia who were conversational, had good family relationships, used formal services, and employed care providers consisting mainly of nursing care support specialists. It is therefore necessary to expand and vary the sample size to conduct further analysis in the future.

\section{Summary}

In this study, we conducted an interview survey of older adults with dementia, their families, and their care providers, and analyzed qualitatively and descriptively the lifestyles desired by the participants and the support of care providers. Older adults with dementia were proud of their life experiences, and hoped to continue doing what they could, live peacefully with their families, go out and interact with others, and live peaceful daily lives. Care providers respected older adults with dementia, elicited what they could do with their current abilities, supported their families, confirmed their satisfaction with life, and helped them make decisions in anticipation of the future. In order to support the lifestyles of older adults with dementia, it is important to ensure that they continue to have dignity as people and that they are safe and secure while living with their families and in communities.

\section{Acknowledgements}

We would like to thank the participants, their families, and their care providers for their cooperation in this study.

The study was funded by JP17K00755 of JSPS Institute of Science and Technology.

\section{Conflicts of Interest}

The author declares no conflicts of interest regarding the publication of this paper.

\section{References}

[1] World Health Organization (2021) Dementia. https://www.who.int/en/news-room/fact-sheets/detail/dementia

[2] Cabinet Office (2017) Annual Report on the Ageing Society. https://www8.cao.go.jp/kourei/english/annualreport/2017/2017pdf e.html

[3] Asada, T. (2018) Epidemiology of Dementia in Japan. Japanese Journal of Geriatric Psychiatry, 29, 350-357. 
https://mol.medicalonline.jp/library/journal/download?GoodsID=aj2rsizd/2018/002 904/003\&name $=0350-0357 j \& U$ serID $=150.46 .200 .54 \&$ base $=$ jamas pdf

[4] Ministry of Health, Labour and Welfare. Comprehensive Survey of Living Conditions 2019. https://www.mhlw.go.jp/toukei/saikin/hw/k-tyosa/k-tyosa19/index.html

[5] Nagaoka, S. and Obuchi, R. (2013) How to Perceive the Scenes of Caring for Elderly with Dementia and the Characteristics of Caring Behaviors of Nurses at Care Health Facilities for the Elderly Requiring Care. Journal of Japan Academy of Gerontological Nursing, 17, 47-57.

[6] Okumura, A., Yamamoto-Mitani, N., Kobayashi, S., Okamoto, Y. and Hukahori, H. (2011) Dementia Homecare Nursing in Japan: A Descriptive Study. Journal of Japan Academy of Home Health Care, 14, 26-33.

https://mol.medicalonline.jp/library/journal/download?GoodsID=ea9nztcr/2011/00 $1402 / 005 \&$ name $=0026-0033 j \& U$ serID $=150.46 .200 .54 \&$ base $=$ jamas pdf

[7] Zarepour, A., Hazrati, M. and Kadivar, A.A. (2020) The Impact of Educational Intervention on the Anxiety of Family Care providers of the Elderly with Dementia: A Randomized Controlled Trial. International Journal of Community Based Nursing \& Midwifery, 8, 234-242.

[8] Lertkratoke, S., Amnatsatsue, K., Kerdmongkol, P. and Nanthamongkolchai, S. (2021) Effectiveness of Thai Integrated Care Program for Older Adults with Dementia in the Community: A Quasi-Experimental Study. Pacific Rim International Journal of Nursing Research, 25, 510-524.

https://he02.tci-thaijo.org/index.php/PRIJNR/article/view/249108/172224

[9] Kubota, M. and Takayama, S. (2017) Elderly with Dementia Living Alone-Personal Experiences Expressed by Elderly with Dementia and Accompanying Dangers Expressed by Care Support Specialists. The Bulletin of Kansai University of International Studies, 18, 23-35. http://id.nii.ac.jp/1084/00000480

[10] Muroya, M. and Kuroda, K. (2020) Investigating Social Support for People with Dementia Living in the Community: An Analysis of the Narratives of Them and Their Family Members. Journal for the Study of Health and Well-Being, 13, 83-96. http://hdl.handle.net/10112/00020070

[11] Westius, A., Andersson, L. and Kallenberg, K. (2009) View of Life in Persons with Dementia. Dementia, 8, 481-499. https://doi.org/10.1177/1471301209350287

[12] Toda, Y., Tanimoto, M. and Harue, M. (2017) The Expression of Older People with Dementia Living in Relationships with Others. Chiba Academy of Nursing Science, 22, 1-10. https://opac.ll.chiba-u.jp/da/curator/102507

[13] Erikson, E.H., Erikson, J.M. and Kivnick, H.Q. (1986/1997) Tomonaga, M. and Tomonaga, R. (Translators) Vital Involvement in Old Age. Misuzu Shobo, Tokyo, 111 136.

[14] Koskenniemi, J., Leino-Kilpi, H. and Suhonen, R. (2015) Manifestation of Respect in the Care of Older Patients in Long-Term Care Settings. Scandinavian Journal of Caring Sciences, 29, 288-296. https://doi.org/10.1111/scs.12162

[15] Ueno, K., Kikuchi, K. and Osada, H. (2017) Japanese Literature Review of "Ibasyo" for Elderly People: For “Aging in Place”. Journal of Gerontological Research, 8, 3350 .

https://obirin.repo.nii.ac.jp/?action=repository action common download\&item i $\mathrm{d}=1971$ \&item no=1\&attribute id=22\&file no=1

[16] Munkejord, M.C., Stefansdottir, O.A. and Sveinbjarnardottir, E.K. (2020) Who Cares for the Carer? The Suffering, Struggles and Unmet Needs of Older Women Caring for Husbands Living with Cognitive Decline. International Practice Devel- 
opment Journal, 10, 1-11. https://doi.org/10.19043/ipdj.10Suppl.005

[17] Park, M., Choi, S., Lee, S.J., Kim, S.H., Kim, J., Go, Y. and Lee, D.Y. (2018) The Roles of Unmet Needs and Formal Support in the Caregiving Satisfaction and Caregiving Burden of Family Caregivers for Persons with Dementia. International Psychogeriatrics, 30, 557-567. https://doi.org/10.1017/S104161021700196X

[18] Toki, H., Tai, M. and Nojima, S. (2019) Review of Literature on Self-Recognition by People with Dementia. Journal of Japanese Society for Dementia Care, 18, 495-505. https://mol.medicalonline.jp/library/journal/download?GoodsID $=$ cxldmnta/2019/0 $\underline{01802 / 011 \& \text { name }=0495-0505 j \& U \text { serID }=150.46 .200 .54 \& b a s e=\text { jamas pdf }}$

[19] Meeker, M., McCullough, K.C., McCullough, G.H. and Akpanudo, U. (2021) Examining Social Networks in Older Adults: What Predicts Communicative Participation? Perspectives of the ASHA Special Interest Group, 6, 933-940.

https://doi.org/10.1044/2021 PERSP-20-00287

[20] Førsund, L.H., Grov, E.K., Helvik, A., Juvet, L.K., Skovdahl, K. and Eriksen, S. (2018) The Experience of Lived Space in Persons with Dementia: A Systematic Meta-Synthesis. BMC Geriatrics, 18, 33. https://doi.org/10.1186/s12877-018-0728-0

[21] Moore, A., Motagh, S., Sadeghirad, B., Begum, H., Riva, J.J., Gaber, J. and Dolovich, L. (2021) Volunteer Impact on Health-Related Outcomes for Seniors: A Systematic Review and Meta-Analysis. Canadian Geriatrics Journal, 24, 44-72.

https://doi.org/10.5770/cgj.24.434 